\title{
FROM DYNAMIC TO STATIC: THE EVOLUTION OF THE RELATIONSHIP BETWEEN THE UK AND THE EUROPEAN COURT OF HUMAN RIGHTS
}

\author{
MERRIS AMOS \\ Professor of Human Rights Law \\ Queen Mary University of London
}

\begin{abstract}
SUMMARY
I. Introduction. II. A framework for assessment. III. 1975-1979. IV. 1980-1984. V. 1985-1989. VI 1990-1994. VII. 1995-1999. VIII. 2000-2004. IX. 20052009. X. 2010-2014. XI. 2015-2017. XII. Conclusion
\end{abstract}

\section{INTRODUCTION}

The UK has had a long relationship with the European Court of Human Rights (ECtHR). It was one of the founding states of the Council of Europe in 1949, ratified the European Convention on Human Rights (ECHR) in 1951 and accepted the right of individual petition to the court in 1966. Up until the end of 2017 the Court has delivered more than 450 judgments concerning the UK and these have varied in the impact each has had at the national level. Some have been static by either helping to preserve the status quo or providing a remedy to the applicant but prompting no wider change. Others have been dynamic and facilitated the improvement of laws, policies and practices in the light of human rights considerations. ${ }^{1}$ At the present time, the relationship between the UK and the Court is essentially a static one. The Court and its jurisprudence operate as a disincentive where breaches of Convention rights are contemplated. Where a violation is found, the Court will usually grant a remedy to the applicant and this will be implemented by the UK but will not result in any wider change. Or it might be that a finding of no violation by the Court supports the government's position and helps it to resist reform on issues such as the regulation of political advertising or the policing of demonstrations.

Instances where a judgment of the Court instigates a process of change or progress in the UK are now very rare. But this has not always been the case. Considering the

1 On the distinction between "static" and "dynamic" impact see further M. Amos, "The Value of the European Court of Human Rights to the United Kingdom” (2017) 28 European Journal of International Law 763-785. 
jurisprudence of the Court in five-year blocks since 1975 until the present, it possible to see the fluctuations in the relationship between the Court and the UK over a long period of time and to determine the periods when the relationship was dynamic, and when it was not, and also to identify what external factors might have played a role. For example, vastly improved national human rights protection via the Human Rights Act 1998 (HRA) since 2000 has clearly contributed to the evolution of a more static relationship as has the recent criticism of the Court emanating from senior UK politicians. Certain indicators can clearly predict the conditions for a dynamic relationship and others show that the relationship is destined to be a static one. The purpose of this article is to trace the evolution of the relationship between the UK and the ECtHR from dynamic to static, and to explain how it has reached this point.

\section{A FRAMEWORK FOR ASSESSMENT}

Categorising more than 50 years of jurisprudence into neat boxes is a complex task and there are some judgments which do not fit neatly into either the "static" or "dynamic" categories. The relationship between the UK and the ECtHR is described as "static" where the status quo is essentially preserved. This can arise in three ways. The existence of the ECtHR and its body of jurisprudence operates as a strong disincentive where UK authorities are contemplating a breach of Convention rights. ${ }^{2}$ However, as this article concerns the impact of the judgments over a period of time, this type of static impact is not considered. Second, and more importantly for the purposes of this article, the ECtHR can hold the UK accountable for its acts incompatible with Convention rights, even if this does not prompt more widespread change at the national level. ${ }^{3}$ Finally, the ECtHR can help the UK government to maintain the status quo in the face of pressure for change. ${ }^{4}$

The relationship between the UK and the ECtHR is described as "dynamic" where it produces change or progress. The UK may prompted by a judgment to improve existing laws, policies or procedures in order to comply with the ECHR. Or, less relevant for the purposes of this article, the jurisprudence of the Court might encourage the adoption of entirely new laws, policies and procedures. This potential of the Court for prompting change is a key finding of Alter: ICs [international courts] are new political actors on the domestic and international stage. Their international nature allows ICs to circumvent domestic legal and political barriers and to create legal change across borders. Their legal nature allows ICs to provoke political change through legal reinterpretation and to tap into diffuse support for the rule of law and pressure governments. Their legal and international nature allows litigants to harness multilateral resources and to knit together broader constituencies of support. ${ }^{5}$

2 K. Alter The New Terrain of International Law (2014) at 23.

3 A. Williams, "The European Convention on Human Rights, the EU and the UK: confronting a heresy", 24 EJIL (2013) 1157 at 1184.

4 K. Alter, n.3 above, at 29.

$5 \mathrm{~K}$. Alter, op cit, at 5 . Simmons reaches the same conclusion in relation to treaty commitments rather than the oversight of an international court. See B. A. Simmons Mobilizing for Human Rights (2009) page 8. 
The period of time analysed in this article starts in 1975 with the first judgment of the Court concerning the UK, Golder $v U K^{6}$ and ends in 2017 with the judgment in $N$ didi $v U K^{7}$. In total this is 454 judgments. Not included are judgments which did not concern the merits but only calculation of the award of just satisfaction and judgments where a friendly settlement was reached. Each judgment may concern more than one applicant but the number of judgments per year has been counted, not the number of applicants. Also not included are the decisions of the European Commission on Human Rights which gave its first decision concerning the UK in 1956 and ceased its work in 1998. The following table gives the number of judgments per each five-year block. 1975/1979 (5), 1980-1984 (7), 1985-1989 (19),1990-1994 (21),1995-1999 (51), 2000-2004 (124), 2005-2009 (108),2010-2014 (88), 2015/2017 (31).

III. $1975-1979$

Given there was no codified constitution or bill of rights at the national level over this period, and the very small number of five judgments, it is not surprising that almost every judgment over this period had a dynamic impact. Judgments where violations of the ECHR were found concerned a prisoner's access to court and contact with a solicitor ${ }^{8}$; judicial corporal punishment on the Isle of $\mathrm{Man}^{9}$; and contempt of court laws which were found to be incompatible with Article $10^{10}$. All were fairly swiftly complied with despite some discussion that the Isle of Man judgment would plunge the UK into "constitutional crisis", this did not eventuate. Much more controversial over this period was the interstate judgment in Ireland $v U K^{11}$ where although the UK's derogation from the Convention was upheld, it was found that methods of interrogation adopted by UK security forces acting in pursuance of emergency powers were inhuman and degrading and in violation of Article 3. But the impact of the judgment was lessened by the fact that Prime Minister Ted Heath had in 1972 announced that the five techniques would no longer be used and the reaction to the judgment was generally neutral although there was some criticism of the Irish government for continuing to the Court with the case despite the findings of the Commission. ${ }^{12}$ The only static judgment over this period was Handyside $e^{13}$ where the Court afforded the UK a wide margin of appreciation over its laws regulating obscene publications and found no violation of Article 10 arising from the conviction of the publishers.

Criticism of the Court over this period was minimal although there was a growing awareness that the UK was consistently topping the league table of the number of applications brought against each state. This was perceived to be not the fault of the Court but the fault of the UK itself given the situation in Northern Ireland, the expulsions in East Africa and the absence of a national remedy. A small number of dynamic changes

\footnotetext{
6 (Appl. No. 4451/70), 21 February 1975

7 (Appl. No. 41215/14), 14 September 2017

8 Golder.

9 Tyrer v UK (Appl. No. 5956/72) 25 April 1978

10 Sunday Times v UK (No.1) (Appl. No. 6538/74) 26 April 1979.

11 (Appl. No. 5310/71), 18 January 1978

12 The Times, Editorial, 14 February 1977

13 (Appl. No. 5493/72), 7 December 1976
} 
were achieved, but a small number of applications were determined. The problems caused by the lack of a national remedy were fully appreciated and there was very little hostility towards the Court.

\section{IV. $1980-1984$}

This period proceeded in much the same fashion. There were only seven judgments and all resulted in dynamic change at the national level ranging from the reform of closed shop agreements ${ }^{14}$ and mental health law $^{15}$ to changes in rules concerning prisoners" correspondence and prison disciplinary proceedings. ${ }^{16}$ Three judgments resulted in very significant change. The judgment in Dudgeon ${ }^{17}$ led to amendment of the law of Northern Ireland so that homosexual acts between two consenting male adults in private was no longer an offence. The judgment in Campbell and Cosans $^{18}$ finding that corporal punishment at school was in violation of Article 2 Protocol 1, but not Article 3, was influential in the passage of the Education Act 1986 which abolished corporal punishment in state schools. And the judgment in Malone $e^{19}$ led to the Interception of Communications Act 1985 to regulate the interception of communications for the first time. But it should not be assumed that the process of change following a judgment of the Court was straightforward. This period was characterised by lots of discussion between different stakeholders about how to best implement the judgment with the judgment itself playing a very important role in the discussion leading up to change. There was enormous respect for the Court and a shared view that its judgments were important and should be implemented. For example, the judgment in Campbell and Cosans concerning corporal punishment in schools, caused considerable debate summed up in the following quote from The Times in 1982: The decision, which must be respected for its cogency in law and by reason of our respect for the treaty, nonetheless poses problems... It is a pity that the European Court could not accompany the right of parents to protect their children from corporal punishment with a corresponding duty to bring up children in a disciplined enough way to make it more likely that they respect authority at school. ${ }^{20}$

Teachers unions were split over the issue and the Minister for Schools at the time was in support of corporal punishment. The government's original plan to grant parents the right to decide was rejected by the House of Lords and eventually, in 1986, the abolition of corporal punishment in state schools was finally achieved. Throughout the debate, respect for the Court was evident although some criticisms were made of the Court by Conservative Party politicians which were eventually to become mainstream. Conservative politician Fred Silvester MP wrote as follows: This is an extraordinary power. Lawyers, nominated by 13 countries, exercise power over the most central

14 Young James and Webster v UK (Appl. No. 7601/76), 13 August 1981

15 X v UK (Appl. No. 7215/75), 5 November 1981 June 1984 .

16 Silver v UK (Appl. No. 5947/72), 25 March 1981 and Campbell and Fell v UK (Appl. No. 7819/77), 28

17 (Appl. No. 7525/76) 22 October 1981

18 (Appl. No. 7511/76) 25 February 1982

19 (Appl. No. 8691/79), 2 August 1984

20 The Times, 26 February 1982, page 11 
political decision of a nation. . the human rights apparatus exercises this political judgment but without reference to democratic institutions elected for this purpose. It assumes that even a country with a free press cannot be trusted to preserve its own freedom. ${ }^{21}$

He called for the UK to end the right of individual petition and later in 1980 launched a campaign to that effect. Similar sentiments were expressed by Enoch Powell, Ulster Unionist MP, who spoke of Britain's “serf masters” the European Court of Human Rights and the European Community. ${ }^{22}$ However, these ideas were not yet supported by government.

One finding of violation over this period did not result in dynamic change, at least in the short term. In both Silver and Campbell and Fell the Court held that Article 13, the right to an effective remedy, had been violated as the applicants had no effective remedy available at the national level. But this part of the Court's judgment, in both cases, was ignored by the UK government and also by the Committee of Ministers. Whilst debates about a UK bill of rights, or incorporation of the Convention into national law, were continuing at the national level, the observations of the government of the day show a mild hostility to the idea and explain why this part of the Court's judgment was not addressed and also why the Court itself changed its mind on Article 13 in 1985. The Lord Chancellor at the time, Lord Elwyn Jones, had said in 1977 that human rights "were not obviously abused" in the UK and that the courts were "far from backward" in ensuring that the powers entrusted by Parliament to the executive were not exceeded. He doubted that there was a need for any further inquiry into a bill of rights suggesting that a better, course might be a general review of the law to see where it "fell short of the convention's ideals" and then remedy any defects. ${ }^{23}$

The 1977 and 1981 bills to incorporate the ECHR into national law made little progress in Parliament despite the fact, as Alan Beith MP explained to Parliament in 1981 , that this would enable grievances to be tested in national courts rather than "continually having to wash its dirty linen in Strasbourg". ${ }^{24}$ There were also calls by senior judges, including Lord Denning, for the ECHR to be incorporated. ${ }^{25}$ But without the support of the ECtHR, and the Committee of Ministers on Article 13, little progress was made.

V. 1985-1989

Over this period the number of judgments increased with 19 judgments, more than the whole of the previous ten years. This period was also characterised by an increase in static judgments either helping the UK to maintain the status quo or holding it accountable, but not prompting any further change. For example, the judgment in Rees $^{26}$ helped

21 The Times, 17 March 1980, page 14

22 The Times, 19 September 1981, page 2

23 The Times, 4 February 1977 , page 4

24 The Times, 9 May 1981, page 3

25 The Times, 11 December 1979, page 2

26 Rees v UK (Appl. No. 9532/81), 17 October 1986 
the UK government to maintain its refusal to legally recognise a change in sex. There was also a reversal of the Court's previous position on Article 13. It did find in Abdulaziz ${ }^{27}$ that the UK's refusal to allow the applicants to join spouses lawfully settled was in breach of Article 14 with Article 8, and Article 13 since the UK had not incorporated the Convention into its domestic law. ${ }^{28}$ However, one year later in its judgment in James $^{29}$ it found no violation of Article 13 stating as follows: The Convention is not part of the domestic law of the United Kingdom, nor does there exist any constitutional procedure permitting the validity of the laws to be challenged for non-observance of fundamental rights. There thus was, and could be, no domestic remedy in respect of the applicants' complaint that the leasehold reform legislation itself does not measure up to the standards of the Convention and its Protocols. The Court, however, concurs with the Commission that Article 13 does not go so far as to guarantee a remedy allowing a Contracting State's laws to be challenged before a national authority on the ground of being contrary to the Convention or to equivalent domestic legal norms. ${ }^{30}$

This reasoning continued to be applied by the Court and no further violations of Article 13 were found over this period thereby removing an important weapon from the hands of those campaigning for incorporation. ${ }^{31}$ On these two issues the conclusion of the Court matched the views of the government. The UK was not ready, at least according to the government of the day, for legal recognition of change in sex or for incorporation of the ECHR into national law. On these two issues, the result was static. But there were a number of judgments over this period leading to dynamic change. A series of judgments relating to child care and wardship where violations of Articles 6 and 8 were found informed important changes in this area including the Children Act 1989. ${ }^{32}$ The judgment in Abdulaziz led to changes in the immigration rules and the removal of a difference in treatment between husbands and wives although it was made more difficult for husbands to bring wives to the UK in order to achieve equality between the two groups. The judgment in $W_{e e k s^{33}}$ that some aspects of life sentencing arrangements were compatible with Article 5 but others were not, was the start of an ongoing battle between the government and the Court over sentencing, something the government was not prepared to adequately address at this point. And the judgment in Brogan ${ }^{34}$ that there had been a violation of Article 5(3) resulting from not bringing a suspected terrorist promptly before a judge resulted in the UK entering a derogation to Article 5.

The judgment with the most lasting impact during this period was Soering. ${ }^{35}$ Here the Court determined that there may be a breach of Article 3 where substantial grounds had been shown for believing that a person subject to extradition faced a real risk of being subjected to torture or to inhuman or degrading treatment in the requesting

27 Abdulaziz, Cabales and Balkdandali v UK (Appl. No. 9214/80) 28 May 1985

28 At [93]

29 James v UK (Appl. No. 8793/79), 21 February 1986

30 At [85].

31 See, for example, Lithgow v UK (Appl. No. 9006/80), 8 July 1986; Boyle and Rice v UK (Appl. No. 9659/82), 27 April 1988; and Soering v UK (Appl. No. 14038/88), 7 July 1989.

32 See, for example, O v UK (Appl. No. 9276/81), 8 July 1987.

33 Weeks v UK (Appl. No. 9787/82), 2 March 1987.

34 Brogan v UK (Appl. No. 11209/84), 29 November 1988

35 Soering v UK (Appl. No. 14038/88), 7 July 1989 
country. ${ }^{36}$ The government informed the Committee of Ministers that it had secured an undertaken from the US that the applicant would not be subject to the death penalty but there were no undertakings as to how this issue would be dealt with in future. It was actually not properly addressed in national law until the HRA came into force on 2 October 2000, but from this point onwards its impact was dynamic, lasting, and significant.

There was still considerable respect for the Court during this period. Following the judgment in Abdulaziz the responsible minister stated that the UK accepted the jurisdiction of the Court and would abide by its decision. ${ }^{37}$ Margaret Thatcher, then Prime Minister, stated in response to the news that notorious murderer Myra Hindley would complain to the Court, that the UK had accepted Article 46 of the Convention and therefore accepted the Court's jurisdiction in all matters concerning interpretation of the Convention. ${ }^{38}$ The right of individual petition was renewed in 1985 with little discussion.

But, echoing sentiments from the earlier period, the judgment in Abdulaziz did give rise to some criticism of the Court in particular, that it was overstepping the boundaries of appropriate judicial behaviour: That characteristic of Strasbourg justice induced the guardian-interpreters of the convention to pass general judgment on public policy to an extent that is foreign to our own judicial system. It draws judges into the false position of deciding questions that properly lie with ministers and legislators. It blurs the constitutional separation of powers. It transmutes rhetoric into law by way of the aggrandizement of judges. ${ }^{39}$

The government's resistance to incorporation of the Convention continued and was supported by the Court's change in its interpretation of Article 13. Undeterred, those supporting a bill of rights continued to campaign and focussed on how a bill of rights would enable UK courts to interpret the ECHR rather than the ECtHR. A bill to incorporate the ECHR was introduced into Parliament in 1986 but failed without the support of the government. When it was reintroduced later that year it was reported that the government was divided over the issue with opponents concerned that it would threaten the supremacy of Parliament and allow courts to make political judgments, something which was seen as unnecessary given there was no evidence of risk to the "liberties of the subject". ${ }^{4}$

VI. 1990-1994

This period was similar to the preceding one with 21 judgments delivered and a fairly even split between static and dynamic judgments. There was no change in the Court's approach to the legal recognition of change in $\operatorname{sex}^{41}$ and the national debate made

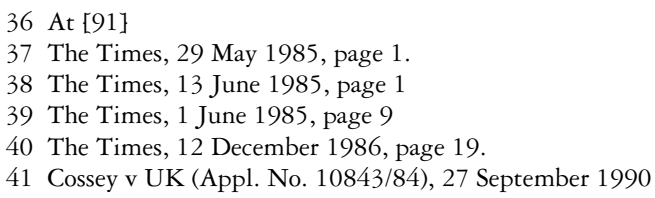


no progress despite a cross party group of MPs trying to get it back on the national agenda. In Costello-Roberts ${ }^{42}$ it held by a narrow margin that "slippering" (being hit by a shoe on the buttocks) at an independent school was not in violation of Articles 3 or 8. This caused some disappointment for campaigners for change given the inequality between treatment in state and non-state schools. The derogation in place to facilitate various laws dealing with the situation in Northern Ireland was upheld ${ }^{43}$ and this also caused some human rights groups to be concerned that the Court was becoming more restrictive and more conservative in its judgments, particularly where the subject of challenge concerned terrorism. ${ }^{44}$ And the Court continued its endorsement of some aspects of life sentencing arrangements for the time being. ${ }^{45}$ The media enjoyed a significant victory with the Court determining that the contempt of court injunctions imposed to prevent publication of the details of the book "Spycatcher" were incompatible with Article 10 but although damages were paid, there was no wider change generated by this judgment. The Court continued its interpretation of Article 13 holding that whilst there were limitations to the powers of national courts exercising judicial review, the courts were able to provide "an effective degree of control" sufficient to satisfy the requirements of Article $13 .^{46}$

There were a number of judgments which led to dynamic change including changes to the availability of legal aid in criminal appeals. ${ }^{47}$ Changes were made to powers in Northern Ireland so that arrest without warrant had to take place with "reasonable grounds" for suspicion. ${ }^{48}$ And the Court found problems with life sentencing arrangements as the applicants were not able to have the lawfulness of their detention decided at reasonable intervals. ${ }^{49}$ In response, the Criminal Justice Act 1991 granted discretionary life sentence prisoners the power to require the Home Secretary to refer the case to the Parole Board which had the power to direct release. The Board was also granted oral hearing and disclosure powers. This caused some concern but the decision was taken in 1991 that government ministers would relinquish their right to decide when prisoners, apart from murderers, serving discretionary life sentences could be released. Politicisation of this issue had not yet occurred and during this period some notorious convicted murderers brought applications to the Court including Myra Hindley and the murderers of toddler James Bulger.

National politics concerning the Court were similar to the preceding period. National judges were beginning to take the jurisprudence of the Court into account in their decision making and the government was still supportive of the Court although in some instances it was now paying compensation to the applicants rather than making the changes which may have prevented the same problem arising again. The debate over a bill of rights or incorporation of the ECHR continued with the record of the UK before the Court becoming a major part of the arguments of campaigners for reform. In an

42 Costello-Roberts v UK (Appl. No. 13134/87), 25 March 1993

43 Brannigan and McBride v UK (Appl. No. 14553/89), 25 May 1993

44 The Times, 27 May 1993

45 Wynne v UK (Appl. No. 15484/89) 18 July 1994

46 Powell and Rayner v UK (Appl. No. 9310/81), 21 February 1990

47 See, for example, Granger v UK (Appl. No. 11932/86), 28 March 1990

48 Fox, Campbell and Hartley v UK (Appl. No. 12244/86), 30 August 1990

49 Thynne, Wilson and Gunnell v UK (Appl. No. 12009/86), 25 October 1990 
important development, it was reported in 1992 that John Smith, the new leader of the Labour Party, wanted to make incorporation party policy. ${ }^{50}$ However, the government of the day continued to maintain that this was not necessary as rights were already protected in national law and Parliament was the best placed to determine rights and liberties. Even the President of the Court, Rolf Ryssdal, was urging the UK to incorporate and claimed it would have a bigger influence on shaping jurisprudence should it do so.

Over this period the UK had settled into a comfortable acceptance that the Court would most likely find a violation of the ECHR, should an application be made to it, and that the government would pay compensation and everything would carry on as normal. Some efforts were even made in Parliament to avert successful challenges although the attempt to equalise the homosexual and heterosexual ages of consent did not succeed, despite the prospect of an unfavourable Court judgment. It was reported in March 1994 that the Home Office had refused to agree to the proposal which would lead to the Court becoming full-time and grant individuals a permanent and automatic right to bring applications. But the government quickly backed down and agreed to sign Protocol 11.

VII. 1995-1999

Over this five-year period the number of judgments doubled with 51 delivered. The Court was becoming well known and in 1993 it was made possible for lawyers to take cases to the Court on a "no win no fee" basis. In 1997 a new Labour Party government was elected on the promise of incorporating the ECHR into national law through a "Human Rights Act" (HRA). One of the major motivations for the HRA was to allow UK courts to determine the issues for themselves without the involvement of the ECtHR. The assumption was that going forward, most issues would be settled in the UK and the ECtHR would no longer have as much influence. The Human Rights Act 1998 came into force in 2000 and whilst it had no impact on the applications before the Court for some time, its passage clearly emboldened the Court in some of the judgments in made over this period such as those concerning the ban on homosexuals serving in the armed forces, the retention of sentencing powers by politicians and ongoing problems with court martials. This was a period where many judgments had a dynamic impact. The HRA also enabled the UK to respond more effectively to the Committee of Ministers given in many instances it would enable judges to solve the incompatibility identified by the Court. ${ }^{51}$ In contrast to previous years, the Court found that the pre-HRA era was essentially in violation of Article 13 concluding in Chabal that removal from the UK would be in violation of Articles 3, 5(4) and 13 given the deficiencies in the removal and habeas corpus proceedings. This judgment resulted in widespread reform of removal in the national security context and the establishment of the Special Immigration Appeals Commission and apparatus to hear this type of case. In relation to Article 13, the Court stated as follows: given the irreversible nature of the harm that might occur if the risk of ill-treatment materialised and the importance the Court attaches to Article 3, the notion of an effective remedy under Article 13 requires independent scrutiny of the

50 The Times, 15 August 1992

51 See, for example, Bowman v UK (Appl. No. 141/1996/760/961), 19 February 1998. 
claim that there exist substantial grounds for fearing a real risk of treatment contrary to Article 3 . This scrutiny must be carried out without regard to what the person may have done to warrant expulsion or to any perceived threat to the national security of the expelling State. ${ }^{52}$

Judgments of the court over this period spurred reform of: court martials ${ }^{53}$; the use of national security certificates in civil proceedings ${ }^{54}$; the use of evidence obtained by compulsory powers ${ }^{55}$; the right to vote in European elections for those living in Gibraltar, a dependent territory of the $\mathrm{UK}^{56}$; the defence of "reasonable chastisement" in relation to the punishment of a child $;{ }^{57}$ the Home Secretary's sentencing powers ${ }^{58}$; the absence of legal aid for some court proceedings ${ }^{59}$; interception of communications ${ }^{60}$; orders for the disclosure of a journalist's source ${ }^{61}$; and the size of damages awards for a successful claim of libel. ${ }^{62}$ Two Article 2 judgments had far reaching implications for the interpretation and application of Article 2 not only in the UK but for all Contracting States. In $\mathrm{McCann} n^{63}$ a violation of Article 2 was found as the planning of the security forces did not meet the requirements of Article 2. Compensation was paid but no further information was provided by the government. And in Osman ${ }^{64}$ the Court developed its Article 2 positive duty jurisprudence finding that the police had a positive duty to protect although it had not been violated on the facts of the application.

The highest profile judgments of this period, leading to dynamic change, were those challenging the ban on homosexual personnel in the armed forces. ${ }^{65}$ In the two judgments the Court concluded that the investigations conducted into the applicants' sexual orientation and their discharge on the grounds of their homosexuality was in violation of Article 8. In January 2000, in response to the judgment, the government lifted the ban. Similar to its conclusion in Chabal, and obviously emboldened by the passage of the HRA at the national level, the Court also found a violation of Article 13 as the applicants had no effective remedy available in relation to the violation of their right to respect for their private lives. It observed as follows: even assuming that the essential complaints of the applicants before this Court were before and considered by the domestic courts, the threshold at which the High Court and the Court of Appeal could find the Ministry of Defence policy irrational was placed so high that it effectively excluded any consideration by the domestic courts of the question of whether the interference with the

52 Chahal v UK (Appl. No. 22414/93) 15 November 1996 at [151].

53 See, for example, Findlay v UK (Appl. No. 22107/93), 25 February 1997

54 Tinnelly \& Sons v UK (Appl. No. 62/1997/846/1052-1053) 10 July 1998

55 Saunders v UK (Appl. No. 19187/91), 17 December 1996

56 Matthews v UK (Appl. No. 24833/94), 18 February 1999

57 A v UK (Appl. No. 100/1997/884/1096), 23 September 1998 —although this was not finally remedied to the satisfaction of the Committee of Ministers until 2004.

58 See, for example, V v UK (Appl. No. 24888/94), 16 December 1999.

59 See, for example, Benham v UK (Appl. No. 19380/92), 10 June 1996.

60 Halford v UK (Appl. No. 20605/92), 25 June 1997 although this was not finally remedied until the coming into force of the Regulation of Investigatory Powers Act 2000.

61 Goodwin v UK (Appl. No 17488/90), 27 March 1996.

62 Tolstoy v UK (Appl. No. 18139/91), 13 July 1995.

63 McCann v UK (Appl. No. 18984/91) 27 September 1995

64 Osman v UK (Appl. No. 87/1997/871/1083), 28 October 1998

65 Smith and Grady v UK (Appl. No. 33985/96) 27 September 1999 and Lustig-Prean and Beckett v UK (Appl. No. 31417/96) 27 September 1999. 
applicants' rights answered a pressing social need or was proportionate to the national security and public order aims pursued, principles which lie at the heart of the Court's analysis of complaints under Article 8 of the Convention. ${ }^{66}$

Whilst there was a lot of dynamism over this period, there were also some static judgments. The Court was developing a sense of what change the national system would accommodate and what it would not. On some of these issues it was to later change its mind. For example, in In Buckley ${ }^{67}$, the first of the planning decisions concerning gypsies to be challenged, the applicant argued that the prevailing legislative arrangements prevented gypsies from pursuing their traditional lifestyle. No violation of the Convention was found. And in Stubbings ${ }^{68}$ the Court decided that there was no violation of the Convention in prohibiting the applicants from bringing legal proceedings in relation to childhood sexual abuse given the offences had occurred outside the time limit set to initiate proceedings. Sensitivity to national prudishness and morality, harking back to Handyside, was also evident over this period with the Court's conclusion in Wingrove ${ }^{69}$ that it was compatible with Article 10 for a film to be refused a classification certificate as it offended the criminal law of blasphemy. Similarly it was held in Laskey ${ }^{70}$ that the conviction of the applicants for criminal offences as a result of consensual activities during sado-masochistic encounters was compatible with Article 8. The Court also maintained its earlier view finding in Sheffield E Horsham $v U K^{71}$ that the non-recognition of a change in sex was not in violation of the Convention and that Article 8 did not impose a positive obligation on the state to recognise a change in sex.

Whilst interest in the Court continued to grow, it was over this period that the government's tone began to change from supportive to critical. Following the judgment in McCann in 1995, Michael Heseltine, the Conservative Party Deputy Prime Minister, denounced a "ludicrous verdict that would give "succour to terrorism". It was reported that the government would ignore the suggestion implicit in the finding that Britain should change its way of conducting anti-terrorist operations. He "did not rule out the possibility of Britain withdrawing recognition from the convention on human rights". Opposition politicians did not join in the criticism of the Court and compensation was eventually paid to the families. ${ }^{72}$ But the criticisms started to grow. In November 1996 it was reported that Conservative Party ministers had called for the Court to reform itself with changes in the way the judges were chosen and how they reach decisions. "It wants the court to pay more heed to British circumstances and traditions": Ministers feel the court has gone beyond its remit by dealing with specific matters that should be left to member states. Britain wants the judges to adopt a more tolerant approach, taking account of "the decisions of local democratic institutions and tribunals, which are best placed to assess issues of this kind". ${ }^{73}$

66 At $[138]$

67 Buckley v UK (Appl. No. 20348/92), 29 September 1996

68 (Appl. No. 22083/93), 22 October 1996.

69 (Appl. No. 17419/90), 25 November 1996.

70 Laskey v UK (Appl. No. 21627/93) 19 February 1997

71 (Appl. No. 31-32/1997/815) 30 July 1998. See also X Y and Z v UK (Appl. No. 21830/93) 22 April 1997.

72 The Times, 28 September 1995

73 The Times, 25 November 196 
The Court did not push any boundaries, particularly with respect to the non-legal recognition of change in sex, around this time. With the election of a new Labour government in 1997 and its promise of incorporation of the ECHR, there was a chance that this new critical stance would be modified. And in the short term this was the case. In 1998 the government did not contest the application brought to the court by a widower claiming that men should have the same benefits as women. It was also making changes, such as equalising the law on the age of consent, to prevent successful challenges in the ECtHR. Following the judgment of the Court in 1999 finding a violation of Article 6 in the trial of the two children who had killed a small child ${ }^{74}$ Home Secretary Jack Straw stated that the government accepted the ruling but he did not immediately outline the changes that would be made. This did not prevent an outpouring of rage from others. Former Home Secretary Michael Howard attacked the Court directly stating that it was unbelievable that it had been used by the two applicants. By contrast, the judgment concerning the armed forces ban on homosexuality was well received. In a statement in October 1999 the Labour Minister for Defence said that "the European court had made its judgment and "we will implement it".

\section{2000-2004}

Given the delays involved in bringing an application to the Court, the coming into force of the HRA did not immediately alleviate the large number applications flowing from the UK to the Court although it did divert some attention towards the national courts. This period was the peak of activity for the UK before the Court with 124 judgments delivered although many of these applications concerned the same issues, such as surveillance or court martials. Also, in many instances, the problem had already been resolved at the national level leaving the Court only to award compensation. Over this time the Labour government did attempt to clean up the mess created by the absence of national human rights protection and very slow change on other issues such as sentencing, prisoners, policing and court martials. Both the HRA and the new Data Protection Act 1998 allowed the government to report to the Committee of Ministers that general measures to remedy the violation found had been taken. Meanwhile the Conservative Party used its conference in October 2004 to propose the repeal or reform of the HRA as it had led to the adoption of "European rights".

As also noted in the preceding period, the new optimism towards human rights law at the national level emboldened the Court and there was a shift to dynamic judgments over this period. However, it was also during this period that the Court delivered its most controversial judgment ever concerning the UK finding that its blanket ban on prisoner voting was incompatible with Article 3 Protocol $1 .{ }^{75}$ The application was referred to the Grand Chamber, a mechanism the UK government was increasingly to avail itself of, and that judgment and its impact is considered in the next section.

Many of the same areas where violations had been found by the Court in the past were back for consideration and judgments of the Court led to reforms in: surveillance

74 T v UK (Appl. No. 24724), 16 December 1999 and V v UK (Appl. No. 24888/94) 16 December 1999.

75 Hirst v UK (No.2) (Appl. No. 74025/01), 30 March 2004 
practices $^{76}$; court martials ${ }^{77}$; the criminal trials of children and young people $\mathrm{e}^{78}$; protection from eviction for gypsies and travellers ${ }^{79}$; protection of union membership ${ }^{80}$; equalisation of benefits for widows and widowers ${ }^{81}$; and improved protection for the lives of prisoners and better investigations into deaths in prison. ${ }^{82}$

Sentencing practices continued to cause difficulties for the UK before the Court. Following a series of adverse judgments ${ }^{83}$ the Secretary of State was prohibited from departing from recommendations of the Parole Board. The Parole Board was made competent to rule on the release of all mandatory life sentence prisoners and damages were available pursuant to Article 5(5). In 2002, in response, and breaking the new Labour government's record of positive engagement with the Court, a defiant tone was adopted by then Home Secretary, David Blunkett. Following the judgment in Stafford ${ }^{84}$ he expressed his disappointment and it was reported he was adamant that politicians and not judges must retain the right to say how long convicted killers must serve. ${ }^{85}$

Difficult issues were raised by the judgment in Ezeh and Connors ${ }^{86}$ where the Grand Chamber found a lack of independence and impartiality in prison disciplinary proceedings. Rules were put in place requiring reference to an adjudicator in serious cases. In such instances prisoners were also given the opportunity to be legally represented. The judgment in Finucane ${ }^{87}$ was one of many judgments concerning the failure of the UK to meet the procedural obligations inherent in Article 2 and properly investigate deaths which had occurred during The Troubles in Northern Ireland. This has been partly resolved by the establishment of the Historical Enquiries Team in late 2005 working with the Police Ombudsman for NI although some matters remain outstanding and are still under the consideration of the Committee of Ministers.

The Court reversed its position on the legal recognition of a change in sex in its judgment in Goodwin ${ }^{88}$. Given the issue was already progressing through the national courts as the result of a HRA claim, it held that the government could "no longer claim that the matter falls within their margin of appreciation" and that the fair balance now "tilts decisively in favour of the applicant". ${ }^{99}$ The issue was eventually remedied by the Gender Recognition Act 2004 which came into force in 2005.

One of the more controversial applications over this period was that in Pretty. ${ }^{90}$ Whilst this was essentially a static judgment, the Court finding that the UK's rules

76 See, for example, Wood v UK (Appl. No. 23414/02), 16 November 2004

77 See, for example, Thompson v UK (Appl. No. 36256/97), 15 June 2004

78 SC v UK (Appl. No. 60958/00), 15 June 2004

79 Connors v UK (Appl. No. 66746/01), 27 May 2004.

80 Wilson v UK (Appl. No. 30668/96), 2 July 2002.

81 Willis v UK (Appl. No. 36042/97), 11 June 2002

82 Edwards v UK (Appl. No. 46477/99), 14 March 2002.

83 See, for example, Stafford v UK (Appl. No. 46295/99) 28 May 2002; Hill v UK (Appl. No. 19365/02) 27 July 2004

84 Stafford v UK (Appl. No. 46295/99), 28 May 2002

85 The Times, 29 May 2002

86 (Appl. No. 39665/98) 9 October 2003

87 (Appl. No. 29178/95) 1 July 2003

88 Goodwin v UK (Appl. No. 28957/95), 11 July 2002

89 Goodwin v UK (Appl. No. 28957/95), 1 July 2002 at [93]. See also I v UK (Appl. No. 25680/94) 11 July 2002

90 Pretty v UK (Appl. No. 2346/02) 2 April 2002 
regarding assisted suicide were not incompatible with the Convention, the Court did find, by contrast to the national courts, that the issue was within the scope of Article 8 thereby opening up the possibility of more litigation at the national level. The judgment in $M c G o n n e l l^{91}$ that arrangements in Guernsey for determining planning appeals were incompatible with independence guarantees set out in Article 6 had implications for judicial arrangements in the highest court, the House of Lords, meaning that the Lord Chancellor himself was risking a violation of Article 6 should he continue to sit on House of Lords panels. The Court also continued to find violations of Article 13 over this period relating to facts arising before the HRA had come into force..$^{92}$ In response, the government was able to submit to the Committee of Ministers that the HRA meant that violations of the Convention could now be considered by national courts.

Whilst dynamic judgments did dominate over this period, there were also some static ones including a number where the Court reconsidered facts, such as those relating to an Article 3 removal decision, and either found a violation or no violation with no need for further reforming measures. ${ }^{93}$ In one instance it clarified its judgment in Osman holding that there was no violation of Article 6 as a result of the striking out of negligence claims against a local authority which had failed to remove children from an abusive situation. ${ }^{94}$ It was also held that an inability to sue a foreign state for torture in the UK was not in violation of Article 3 or Article 6, a conclusion the Court would adhere to when the issue came before it again in future years. ${ }^{95}$ And it was held in $\mathrm{McVicar}^{96}$ that the unavailability of legal aid in defamation proceedings was not in violation of Articles 6 or 10. Controversy was avoided in Appleby where the Court held that for a private shopping centre to prohibit the distribution of leaflets with a political message did not mean that the state was in breach of Articles 10, 11 or $13 .{ }^{97}$ And in the Grand Chamber judgment in Hatton, reversing the Chamber judgment, political difficulties were avoided with the conclusion that night flights at Heathrow were not in violation of Article 8 rights although a violation of Article 13 was found. ${ }^{98}$ The government had claimed the Chamber judgment was "seriously flawed". The Court was not willing to get involved in the national position on assisted suicide and although in its judgment in Pretty it found that the facts came within the scope of Article 8, it found no violations of Articles 2, 3, 8, 9 or $14 .{ }^{99}$

IX. 2005-2009

Over this period the number of judgments started to decline. Whilst 108 were delivered, more than 30 percent concerned applications from widowers complaining about inequality of benefits when compared with widows, an Article 14 violation which

91 (Appl. No. 28488/95) 8 February 2000

92 See, for example, Hatton v UK (Appl. No. 36022/97), 8 July 2003.

93 See, for example, Bensaid v UK (Appl. No. 44599/98), 6 February 2001.

94 Z v UK (Appl. No. 29392/95) 10 May 2001.

95 Al-Adsani v UK (Appl. No. 35763/79) 21 November 2001.

96 (Appl No. 46311/99) 7 May 2002

97 Appleby v UK (Appl No. 44306/98) 6 May 2003.

98 Hatton v UK (Appl No 36022/97) 8 July 2003

99 Pretty v UK (Appl No 2346/02) 29 April 2002 
had already been conceded by the government. The number of dynamic judgments was also in decline and many judgments over this period concerned issues which had already been addressed such as court martials, legal aid, and aspects of criminal law procedure. The HRA was beginning to have an impact and many of the applications determined by the Court over this period had already been considered by the national courts. It was becoming clear that in such instances, it was unlikely, although not impossible, for the Court to reach the opposite conclusion. Whilst the Labour government was trying to clear the backlog, settle longstanding disputes and generally be respectful of the Court, some of the Court's most controversial judgments concerning the UK were delivered over this period including the Grand Chamber's conclusion that the blanket ban on prisoner voting was incompatible with Article 3 of Protocol No.1.

Judgments with dynamic impact over this time included $S$ and Marper ${ }^{100}$ where the Grand Chamber held, contrary to the House of Lords, that the blanket retention of DNA profiles and samples by police engaged Article 8 and was incompatible with it. This took a very long time to remedy at the national level with no legislation until 2012 and a clarifying judgment of the Supreme Court in 2011 where it was recommended the code of practice be amended to ensure compliance. ${ }^{101}$ In Dickson ${ }^{102}$, decided in 2007, the Grand Chamber determined that it was incompatible with Article 8 for a prisoner to be denied access to artificial insemination. The issue had been considered by the Court of Appeal which had found in favour of the government although it was a different applicant before the Court. The government amended the policy to include a proportionality test. The most high profile and politicised judgment ever concerning the UK was delivered in Hirst No. ${ }^{103}$ Here the Grand Chamber confirmed that the UK's blanket ban on prisoner voting was incompatible with Article 3 Protocol 1 prompting a national debate which lasted for 12 years. Only in 2017 was the issue resolved to the satisfaction of the Committee of Ministers with the UK promising to grant the vote to prisoners released on temporary licence and prisoners released on home detention curfew although it was estimated that this would only affect 100 prisoners at any one time.

Over this period a dialogue between the ECtHR and national courts began in earnest. One example is $\mathrm{McCann} n^{104}$ where the Court found that the termination of a tenancy without the opportunity for the applicant to test the proportionality of the measure was in violation of Article 8. This was eventually clarified by the UK Supreme Court in its judgment in Pinnock. ${ }^{105}$ A dialogue also arose from the judgment in Tsfayo ${ }^{106}$ where it was held that housing benefit review boards were not independent and impartial. This was resolved in 2001 with the establishment of tribunals independent of the local authority but the issue of independence in such instances continues to cause difficulties before the national courts. Unusually there was also an application where a violation had been found at the national level but it was accepted by the Court as it contained an Article 13 claim which it is not possible to make under the HRA. As the violation was a result of primary legislation, the

100 (Appl. No. 30562/04) 4 December 2008

101 R. (GC) v Commissioner of Police of the Metropolis [2011] UKSC 21

102 Dickson v UK (Appl. No. 44362/04), 4 December 2007

103 (Appl. No. 74025/01) 6 October 2005

104 (Appl. No. 19009/04) 13 May 2008

105 [2011] UKSC 6

106 (Appl. No. 60860/00) 14 November 2006 
applicants had only received a declaration of incompatibility at the national level and no other remedy such as damages. The Court, nevertheless, found that the declaration of incompatibility was not a remedy incompatible with Article 13 and agreed with the national court, the House of Lords, on the invalidity of the derogation and the subsequent violations of Article 5 and recommended Article 5(5) compensation. ${ }^{107}$

There were also some judgments which should have resulted in dynamic change but only resulted in measures to satisfy the individual applicant. For example, in Financial Times ${ }^{108}$ the Court had found a violation of Article 10 as a result of a court order obliging the FT to provide documents for the purpose of identifying an anonymous source. The government paid compensation and distributed the judgment but did not change the law which allowed this type of order.

There was definitely a shift towards static judgments over this time and some very controversial matters were found compatible with the Convention by the Court where previously, if the matter had not been considered at the national level, it is likely that the Court would have found a violation. One example is Roche ${ }^{109}$ where a claim against the Ministry of Defence was prohibited by law. The Court was clearly influenced by national HRA judgments concerning the same issue and found that Article 6 (access to court) had no application to the facts and therefore had not been violated. However, a violation of Article 8 was found in respect of the lack of information. The application in Evans $^{110}$ raised an emotive issue which had already been determined against the applicant at the national level. Under national law, embryos the applicant had created with her former partner were to be destroyed as he had withdrawn his consent and she had no other chance of having her own biological children. Affording a wide margin of appreciation the Court found no violation of the Convention. In Saadi111 the Court reached the same conclusion as the national courts that immigration detention was not in violation of Article 5(1) although there was a violation of Article 5(2) in respect of the lack of reasons provided for detention. And in $N v U K^{112}$ the Court agreed with the national courts, even adopting the wording utilised by the House of Lords, that the removal of the HIV positive applicant to Uganda was not incompatible with Article 3 as this was not a very exceptional case. The Court's reluctance to get involved in national pension matters was evident in Carson ${ }^{113}$ where in agreement with the national courts, it found that the refusal to uprate the pensions of those living abroad in certain states, in line with inflation, was compatible with Article 14.

Whilst there had been some comments from government ministers critical of the Court in the preceding period, over this period the tenor of the debate became much more critical. Following a terror attack in London in July 2005, Prime Minister Tony Blair announced that the "rules of the game are changing". Shortly after, Home Secretary Charles Clarke advised the judiciary not to "thwart efforts to deport foreign terrorist suspects" and called for a review of the ECHR. In May 2006 Tony Blair launched an

\footnotetext{
107 A v UK (Appl. No. 3455/05) 19 February 2009.

108 (Appl. No. 821/03) 15 December 2009

109 Roche v UK (Appl. No. 32555/96) 19 October 2005

110 (Appl. No. 6339/05) 10 April 2007

111 (Appl. No. 13229/03) 29 January 2008

112 (Appl. No. 26565/05) 27 May 2008

113 (Appl. No. 42184/05) 16 March 2010
} 
attack on human rights law and courts stating that it was time for a profound rebalancing of the debate on civil liberties "to ensure that wrongdoers pay the penalty for breaking the rules". Meanwhile the Conservative Party announced its plans for a British Bill of Rights to replace the HRA although little detail was provided.

\section{2010-2014}

Over this period the number of judgments did fall with 88 judgments recorded. Issues before the Court became more complex and, in most instances, had often already been considered by national courts utilising the HRA. This made the task of the Court more politicised and the number of dynamic judgments fell although there were some and, in a few instances, these caused considerable controversy.

Some judgments concerned matters where a violation had previously been found by the Court such as the failure to effectively investigate deaths which had occurred during The Troubles in Northern Ireland and there were also further judgments concerning the blanket ban on prisoner voting although the Court did not change its view that this was in violation of Article 3 of Protocol $1 .{ }^{114}$ There were also continuing problems coming to the Court concerning the release of prisoners and the operation of the Parole Board. ${ }^{115}$ Immigration detention became a problem the Court finding a violation of Article 5 in the application of $A b d i^{116}$ given its conclusion that his detention was no longer for the purpose of his removal. And there was disagreement with national courts over sweeping stop and search powers which the Court found to be not in accordance with the law although its judgment resulted in swift legislative change. ${ }^{117}$

Some judgments contained both static and dynamic elements. For example, in $M c D$ onald ${ }^{118}$ the Court concluded that a local authority's decision to withdraw nighttime care was within the scope of Article 8 but only found a minor violation on prescribed by law grounds and did not find the withdrawal of care to be disproportionate overall. And in MGN Limited ${ }^{119}$ it was determined that there was no violation of Article 10 as a result of a national HRA privacy claim, but there was a violation as a result of the success fees charged by the lawyers which the unsuccessful newspaper had to pay. This issue has yet to be resolved to the satisfaction of the Committee of Ministers.

In some instances the Court was making determinations which matched those already arrived at by courts at the national level utilising the HRA, although not in relation to the claim of the applicant before the Court. For example in Paulet ${ }^{120}$ it approved the later position adopted by the UK Supreme Court in relation to confiscation orders which had not been utilised by the national courts in relation to the applicant's claim. Or the Court considered issues which had already been remedied by law at the national level such as its

114 See, for example, Firth v UK (Appl. No. 47784/09), 12 August 2014.

115 See, for example, Betteridge v UK (Appl. No. 1497/10), 29 January 2013.

116 (Appl. No. 27770/08) 9 April 2013

117 Gillan v UK (Appl. No. 4158/05) 12 January 2010

118 McDonald v UK (Appl. No. 4241/12) 20 May 2014

119 (App. No. 39401/04) 18 January 2011

120 Paulet v UK (Appl. No. 6219/08) 13 May 2014 
judgment in $\mathrm{CN}^{121}$ where it found a violation of Article 4 due to the absence of laws penalising forced labour and servitude, such laws had already been put in place by the time the judgment was delivered. And the discrimination against same sex partners found in $J M^{122}$ has already been remedied by the Civil Partnerships Act 2004.

In other applications the Court was given the opportunity to clarify some of its own jurisprudence. For example, in Eweida ${ }^{123}$ it held that where Article 9 was at issue in the workplace, rather than deciding the applicant could accept another role or find another job, it was preferable to consider the necessity for the interference rather than finding no interference at all. There was no need for legislative change as the Court's new interpretation was implemented by national courts. In fact, the need for legislative change to remedy violations became far rarer over this period.

One of the most controversial judgments over this period was Vinter ${ }^{124}$ which was widely misreported in the UK media. Here the Court determined that whilst it was possible for a whole life sentence to be compatible with Article 3, there needed to be a review at some point and it recommended this occur at around 25 years. As this was not adequately set out in UK law, the Court found a violation of Article 3 leading some newspapers to report that the Court had ordered the release of numerous notorious murderers. Also controversial were judgments of the Court impacting on immigration decisions at the national level. These were not well received by the UK government and this was particularly acute where the Court held that the removal of Abu Qatada (Othman $)^{125}$ to Jordan would be incompatible with Article 6 given the real risk of a flagrant denial of justice resulting from the possibility of the admission of torture evidence at his trial. Given the considerable national jurisprudence on the question, including a judgment of the UK Supreme Court, the judgment of the Court was particularly lengthy including international and comparative material to help show that it was appropriately reasoned.

Over this period on many issues a dialogue was taking place between national courts and the ECtHR although it was a dialogue operating over a very long period of time and more often than not resulted in the Court reaching the same conclusion as the national courts, particularly where the Grand Chamber was considering a controversial issue. But this was not the case with its judgment in Al-Skeini ${ }^{126}$ one of the most controversial and far reaching of all the judgments of the Court concerning the UK. The Court determined that the Convention had a different and more extensive extraterritorial effect than that which the UK Supreme Court had given it. In short, it applied to the activities of UK armed forces in Iraq and there was therefore a duty on the UK to investigate the civilian deaths which had occurred. This dynamic change did not require legislation but national courts, once the judgment was adopted by the UK Supreme Court, interpreted the HRA in a similar fashion, giving it an extra-territorial reach it did not previously have. The Iraq Historic Allegations Team was set up to conduct investigations into this type of death. It is resourced until December 2019 and has a lifetime budget of $£ 57.2$ million.

121 (Appl. No. 4239/08) 13 November 2012

122 (Appl. No. 37060/06) 28 September 2010

123 (Appl. No. 48420/10) 15 January 2013

124 Vinter v UK (Appl. 66069/09) 9 July 2013

125 (Appl. No 8139/09) 17 January 2012

126 Al-Skeini v UK (App. No. 55721/07) 7 July 2011 
But this period stands out more for the number of static judgments where the Court found no violation of the ECHR particularly those concerning controversial issues which had already been exhaustively considered by national courts utilising the HRA. There are a number of examples. In $\operatorname{Carson}^{127}$ the Court held, in agreement with the highest national court, the House of Lords, that the failure of the UK to uprate pensions for the applicants, who were living abroad, was not in violation of Article 14 with Article 1 Protocol 1. The Regulation of Investigatory Powers Act 2000 was held to be compatible with Article 8 in Kennedy ${ }^{128}$. In Al-Khawaja and Tahery ${ }^{129}$ the Grand Chamber, taking careful note of judgment of the UK Supreme Court on the issue and also taking into account a variety of comparative material, determined that the admission of statements in criminal trials without the possibility of examination or cross examination of the witness was not automatically in violation of Article 6. In Austin ${ }^{130}$, again in agreement with the highest national court, the Court concluded that police "kettling" or containment of demonstrators did not engage Article 5 as there was no deprivation of liberty. It was also held in Animal Defenders ${ }^{131}$ that the UK's blanket ban on political advertising on radio or television was compatible with Article 10. The Court took particular note of the view of the national court and Parliament on the issue.

In May 2010 a new coalition government between the Conservative Party and Liberal Democrats took office. At first, respect for the Court was intact and judgments were implemented rather than openly defied or criticised. The violation found by the Grand Chamber in 2005 as a result of the blanket ban on prisoner voting ${ }^{132}$ had still not been remedied and in September 2010 the new government promised to do something about it. But rather than present a plan which was then to be implemented, it prevaricated and allowed the issue to blow out of all proportion becoming a magnet for all of those who wished to criticise the Court and the UK's relationship with it. Prime Minister David Cameron showed little leadership and was reported to be exasperated and furious at having to implement the judgment. The matter was further politicised when a number of prisoners lodged applications with the Court on the same issue. Politicians from all political parties, including former Labour Home Secretary Jack Straw, opposed any reform which would enfranchise prisoners. By January 2011 the debate was out of proportion. In an editorial in The Times, it was stated as follows: If MPs decide that prisoners should not be granted the franchise, as they surely must, they should not be. If this defiance of rulings made in Strasbourg is to prove complicated, $\mathrm{Mr}$ Cameron must be clear that this is not a problem for over here, but one for over there. ${ }^{133}$

The issue became a battle for national sovereignty with the Prime Minister calling for MPs to vote against allowing prisoners the vote and they voted by 234 to 22 to defy the ruling of the Court with the parliamentary debate centring on Parliament losing its sovereignty "the poodle of a European court' according to David Ruffley MP. From then on, the issue of prisoner voting was mentioned every time the Court was mentioned,

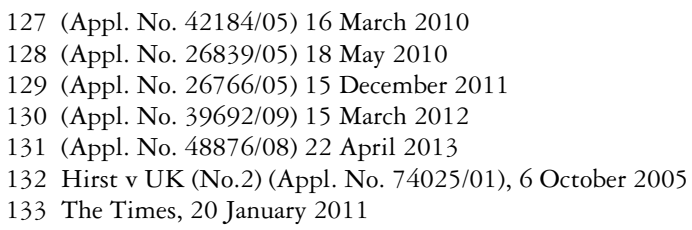


regardless of the context or the issue. In December 2013 a special parliamentary committee recommended that all inmates serving less than 12 months should get the vote. A new compromise was considered in March 2014 and in August 2014 the ECtHR determined that damages would not be awarded and no compensation and no costs to any prisoner applicant. Former Home Secretary Jack Straw wrote in the Times: The problem the Strasbourg court has created for itself — and for us - over the years has therefore lain not in the terms of the convention, but in the way in which the court stretched to breaking point the intentions of those nations that signed the treaty. It has sought to turn itself into a supreme court for Europe... one for which no democratic override was available. ${ }^{134}$

Opinion pieces calling for withdrawal from the ECHR proliferated in national newspapers. The language the Prime Minister and the Home Secretary used in relation to national courts and the ECtHR deteriorated with both "appalled" at the judgment of the Supreme Court in a HRA case and stating that "it is about time we ensured that decisions are made in this Parliament rather than in the courts". Human rights law was being blamed for many problems with Prime Minister David Cameron even linking human rights to the London riots of August 2011. Ambitious ministers and members of parliament criticised the Court in order to bolster their own personal ambitions.

Abu Qatada (Othman) won his application in the ECtHR in January 2012 that his extradition to Jordan would be incompatible with Article 6. This prompted the Prime Minister David Cameron to warn that the ECtHR risked falling into disrepute "if it continues to overturn rulings by sovereign states". On 25 January 2012 in a speech to the Council of Europe in Strasbourg, he said he wanted the Court to only deal with the most serious violations of human rights. Qatada was granted bail and ministers made clear their dismay. In an editorial The Times it was stated as follows: It is right that human rights be considered a supranational concern. Yet the ECHR's actions once again look like an affront to national sovereignty, let alone common sense. Britain is still attempting to feel its way towards a solution to the same Court's ruling last year that prisoners should be given the vote... This is Britain's problem, but Strasbourg's failure. ${ }^{135}$

Following the judgment in Vinter the Prime Minister's spokesman said he was "very, very, very, very disappointed and that he would not rule out withdrawing from the court if the Conservatives win the next general election." In October 2014 the Conservative Party published its plans to reform human rights law in the policy paper Protecting Human Rights in the $U K{ }^{136}$ In the proposals, it is stated that the recent practice of the ECtHR "and the domestic legislation passed by Labour" has damaged the credibility of human rights at home. ${ }^{137}$ The treatment of the ECHR as a "living instrument" or the practice of "evolutive interpretation" by the Court was subject to strong criticism: Even allowing for necessary changes over the decades, the ECtHR has used its "living instrument doctrine" to expand Convention rights into new areas, and certainly beyond what the framers of the Convention had in mind when they signed up to it. ${ }^{138}$

134 The Times, 14 August 2014

135 As reported in The Times, 8 February 2012

136 Conservative Party, Protecting Human Rights in the UK (London: Conservative Party, 2014).

137 p. 3.

138 p. 3. 
The judgments of the Court utilised to illustrate the points made included: prisoner voting; artificial insemination for some prisoners; ${ }^{139}$ and (generally) the prevention of the deportation of foreign nationals who have committed crimes. The whole life tariff judgment of the Court in Vinter ${ }^{140}$ was also mentioned, although the interpretation of the judgment was incorrect. The plans for reform of the ECHR system included in the proposals were to make the judgments of the ECtHR "no longer binding over the UK Supreme Court" and for it to be "no longer able to order a change in UK law", as it was to become an "advisory body only". ${ }^{141}$ It was promised that, should the Council of Europe not agree to this approach, the UK would withdraw from the ECHR.

Over this period the ECtHR itself changed and allowed far more freedom for States to adopt a more flexible and nationally focussed interpretation of international human rights guarantees and jurisprudence. The UK has actually utilised the concept of consensus and living instrument in ECtHR litigation to its advantage in order to halt a more expansive interpretation. ${ }^{142}$ Spano writes of the "age of subsidiarity' and states that the Court is consistently demonstrating its willingness to "defer to the reasoned and thoughtful assessment by national authorities of their Convention obligations' utilising the judgment of the Court in Animal Defenders $v U K^{143}$ and Protocols 15 and 16 to support his argument. ${ }^{144}$ The ECtHR does take account of the processes of national authorities in its determination of the margin of appreciation. Saul has referred to the "growing body of case law that supports the thesis of deeper subsidiarity in relation to parliaments'. ${ }^{145}$ Mahoney writes of the role played by national courts: the closer the analysis of the national courts reflects the European Convention and its case-law, the more likely the finding will be that the national courts have remained within the domestic margin of appreciation... There will be less temptation for the Strasbourg Court to engage in micro-management of individual situations or even in reviewing the preceding policy-making and, thus, less inclination to disturb the rulings of the national courts if the national courts are visibly operating domestic remedies with an eye to compliance with Convention standards and case law. ${ }^{146}$

As Mahoney notes, UK courts have a much greater chance of retaining control of the interpretation and application of human rights law if a co-operative, rather than a "hierarchical or competitive relationship" is maintained. ${ }^{147}$ Where State authorities do a good job, fulfilling their responsibilities as the primary guarantors of Convention rights,

139 Dickson v. UK (Appl. no. 44362/04), 4 December 2007.

140 (Appl. no. 66069/09), 9 July 2013.

141 As the UK is a dualist system, these statements in the proposals were also misleading.

142 See further C. DraghicI, "The Strasbourg Court between European and local consensus: anti-democratic or guardian of democratic process?" [2017] PL 11.

143 Animal Defenders International v United Kingdom ECtHR 22 April 2013.

144 R. Spano, “Universality or Diversity of Human Rights: Strasbourg in the Age of Subsidiarity' (2014) 14 HRLR 487, 491.

145 M. SAUL, "The European Court of Human Rights' Margin of Appreciation and the Processes of National Parliaments' (2015) 15 HRLR 745, 773-774.

146 P. Mahoney, "The relationship between the Strasbourg Court and the national courts" (2014) Law Quarterly Review 568 at 571.

147 Ibid at 586. See also E. BAtes, "Analysing the prisoner voting saga and the British challenge to Strasbourg” (2014) 14 Human Rights Law Review 503 at 533. 
the ECtHR will respect this. ${ }^{148}$ It is also becoming increasingly harder for applicants to access the Court, although this has also generated some criticism. ${ }^{149}$ Over the years UK judges have become far more adept at carefully adjudicating in HRA cases so as to secure respect for their work should it end upon on review before the ECtHR. In some instances: British courts can now exert strong influence [on the ECtHR], changing the course of Convention jurisprudence for all Contracting States, and help to ensure that where the UK wishes to maintain a national position on an important issue, such as its ban on political advertising, this is far more possible than might have otherwise been the case. ${ }^{150}$

XI. 2015-2017

It is not surprising that in the three years following the most vehement attacks on the Court to date that the number of judgments has declined and that there has been an even more marked shift towards static judgments. Violations have been found in relation to issues which have been problematic for some time - prisoner voting, delays in Parole Board hearings and immigration detention but there has been only one judgment over this period with a slight dynamic element. In $R E^{151}$ the Court found that some aspects of surveillance legislation were not in accordance with law and a violation of Article 8 was found which was swiftly rectified.

Apart from these, almost all of the judgments over this period have been static. Some were simple reconsiderations of fact scenarios and no violation found. Others concerned more controversial issues and the finding of no violation signalling a new willingness on the part of the Court to stay out of matters which had been exhaustively considered by national courts adjudicating with the HRA. For example, in Fazia Aliv $U K^{152}$ the Court held that the inability to appeal to an independent and impartial tribunal on a social housing matter was not in violation of Article 6 as the judicial scrutiny available via judicial review was sufficient to satisfy Article 6. In $D a$ Silva ${ }^{153}$ it held that a decision not to prosecute was not in violation of Article 2 and that the procedural obligations incurred under Article 2 did not extend this far. Ibrabim ${ }^{154}$ concerned the controversial issue of lack of access to a lawyer during the initial questioning at a police station and admission of statements obtained at a subsequent trial. No violation of Article 6 was found in relation to the first three applicants although a violation was found in relation to the fourth applicant.

The British Gurkha Welfare Society was unsuccessful in its argument that their lower pension entitlement compared to other ex-service personnel was incompatible with Article

148 See further, A. Mowbray, "Subsidiarity and the European Convention on Human Rights" (2015) 15 HRLR 313; M. Saul, "Structuring evaluations of parliamentary processes by the European Court of Human Rights" (2016) 20 The International Journal of Human Rights 1077; and O. ARNARDóTTIR, "The procedural turn under the European Convention on Human Rights and presumptions of Convention compliance" (2017) 15 IJCL 9.

149 See, for example, A. TICKELL, "More "efficient' justice at the European Court of Human Rights: but at whose expense?" [2015] PL 206.

150 M. AMOS, "The influence of British courts on the jurisprudence of the European Court of Human Rights"

IN R. MCCORQuOdALE and J. Gauci (eds.) British Influences on International Law 1915-2015 (London: BRILL, 2016).

151 RE v UK (Appl. No. 62498/11) 27 October 2015

152 (Appl. No. 40378/10) 20 October 2015

153 (Appl. No. 5878/08) 30 March 2016

154 (Appl. No. 50541/08) 13 September 2016 
14. ${ }^{155}$ The Grand Chamber in Hutchinson ${ }^{156}$ settled the controversy which had arisen following the judgment in Vinter by finding that the problem with lack of clarity concerning the period at which the review of a whole life sentence would take place had been resolved by a judgment of the UK Court of Appeal and the violation of Article 3 had been remedied. Finally, immigration rules guiding judicial discretion when removal is alleged incompatible with Article 8 were put to the test in $N d i d i^{157}$ and the Court found no violation of Article 8 stating as follows: The requirement for "European supervision" does not mean that in determining whether an impugned measure struck a fair balance between the relevant interests, it is necessarily the Court's task to conduct the Article 8 proportionality assessment afresh. On the contrary, in Article 8 cases the Court has generally understood the margin of appreciation to mean that, where the independent and impartial domestic courts have carefully examined the facts, applying the relevant human rights standards consistently with the Convention and its case-law, and adequately balanced the applicant's personal interests against the more general public interest in the case, it is not for it to substitute its own assessment of the merits (including, in particular, its own assessment of the factual details of proportionality) for that of the competent national authorities. The only exception to this is where there are shown to be strong reasons for doing so... ${ }^{158}$

There was still criticism of the Court from government up until the June 2016 referendum on leaving the EU. High profile support for withdrawal from the ECHR was provided by current Prime Minister Theresa May, who, when Home Secretary in April 2016, gave a speech supporting the UK staying in the EU, but leaving the ECHR, illustrating her case with the deportations of Abu Hamza and Abu Qatada, ${ }^{159}$ which had been delayed by applications to the ECtHR, and the fact that the ECtHR "tried to tell Parliament that - however we voted - we could not deprive prisoners of the vote". She summed up her opinion of the Court as follows: The ECtHR can bind the hands of Parliament, adds nothing to our prosperity, makes us less secure by preventing the deportation of dangerous foreign nationals - and does nothing to change the attitudes of governments like Russia's when it comes to human rights. ${ }^{160}$

In 2016, with the change in government leadership following the decision to implement the Brexit referendum result and leave the European Union, the Conservative government's hard-line stance on the ECtHR has softened a little. The Conservative Party formed a government again following the 2017 general election but all focus is now on Brexit. The promise is not to repeal or replace the HRA whilst the process of Brexit is underway and to "remain signatories to the European Convention on Human Rights for the duration of the next parliament." 161

155 British Gurkha Welfare Society v UK (Appl. No. 44818/11) 15 September 2016

156 (Appl. No. 57592/08) 17 January 2017

157 (Appl. No. 41215/14) 14 September 2017

158 At $[76]$

159 Ahmad v. United Kingdom (Appl. no. 24027/07), 10 April 2012; Othman (Abu Qatada) v. United Kingdom (Appl. no. 8139/09), 17 January 2012.

160 In a speech in June 2016 prior to becoming Prime Minister, she promised that she would not lead the UK out of the ECHR as she appreciated that she did not have the numbers in Parliament to achieve this. See further https://rightsinfo.org/breaking-theresa-may-will-not-try-leave-european-convention-human-rights/ (last accessed 10 May 2017).

161 Conservative Party Forward Together (London: Conservative Party 2017) page 37. 


\section{CONCLUSION}

The UK provides an interesting study of how the relationship between a state and the ECtHR can develop over time. Over more than 40 years the relationship has gone from one that was almost always dynamic to one that is now almost always static. The experience of the UK shows that a dynamic relationship can flourish in the absence of effective national human rights protection through law. But this is not the only factor necessary. There must also be a sufficient number of applications flowing to the Court, respect for the Court from leading political actors, as well as a willingness to appreciate that the UK institutions may have overlooked something important or made a mistake. Furthermore, there must be willingness to remedy the violation as found by the Court, to the satisfaction of the Committee of Ministers, and the political leadership to implement a change in the national approach. This is best illustrated by the approach of the Court to Article 13 and the lack of remedies in the UK. Whilst at first the Court found the absence of national remedies was in violation of Article 13, it quickly accommodated the message from government that the UK was not ready for incorporation or a bill of rights. Article 13 violations were only found again once the HRA was in place.

By contrast, a relationship between a state and the Court is more likely to be static where there is effective national human rights protection through law. Over the years the Court has adjusted its own principles of interpretation to better respect the outcomes from states where national institutions have carefully considered human rights issues before acting. The experience of the UK also illustrates that a vigorous national campaign against the Court, and the threat of withdrawal from the ECHR, can also contribute to the relationship becoming a more static one.

But it is important not to give the impression that just because the relationship between the UK and the ECtHR is currently static, the relationship is no longer of any value to a state committed to the protection of human rights through law. The Court continues to act as a strong disincentive where there is a temptation to breach the ECHR. It provides justice and a remedy to those who might not have a remedy at the national level for the violation of their rights. And it can help to maintain the status quo in the UK by confirming the national courts' interpretation and application of human rights norms to controversial issues, granting a finality to national debates and confirming that the UK's commitment to protecting human rights through law is working.

However, the downsides to a permanently static relationship must also be appreciated. For the continued effectiveness and survival of the ECHR system of protection, it is important for the judgments of the ECtHR, and the system as a whole, to be perceived as legitimate by applicants, NGOs and other stakeholders as well. This should not be underestimated, as Alter has observed: [...] where ICs [international courts] lack domestic support constituencies, governments can defend non-compliance with international rules as consistent with the domestic rule of law. But where there are government and nongovernmental actors who do prefer to follow international law, ICs can help construct coalitions of counterpressures that alter the political balance in favour of policies that better cohere with international legal obligations. ... ICs become politically weak not because governments oppose them. ... Rather, ICs become politically weak when 
legal and policy defenders will not organise to demand that governments adhere to the particular legal covenants or to the particular interpretations of the law the IC is promoting. ${ }^{162}$

The disappointment with recent judgments where the ECtHR has found the UK not in violation of the EHCR is growing, and questions of legitimacy are being raised by various non-governmental actors. According to Fenwick, "reliance on finding a European consensus in socially sensitive contexts can merely lead to acceptance of detrimental treatment of groups traditionally vulnerable to discrimination." 163 Draghici observed that "methodologically flawed findings... expose the Court to criticism and mistrust", ${ }^{164}$ and in Henrard's opinion, the Court may well be losing the very legitimacy it is trying to maintain when it sacrifices the effective protection of fundamental rights to "keep states on board". ${ }^{165}$ Judgments like Animal Defenders International, in which the weight of consensus clearly indicated a different conclusion from that reached by the Court, can be perceived as arbitrary and, in the opinion of some, an example of a Court deciding in accordance with its assumption of what the system can bear, rather than deciding in accordance with the weight of persuasive authority and other important principles. ${ }^{166}$

On the other hand, it might be time to accept that the Court's role in prompting new directions in the protection of human rights in the UK is now much reduced, particularly in light of the fact that national human rights protection under the HRA, at least for the moment, encourages detailed consideration of these issues by the legislature, executive or judiciary prior to an application to the ECtHR. In short, as McGoldrick notes, on some issues, such as the prohibition of sexual orientation discrimination, progress at the national level may achieve more than the Council of Europe: [...] strategic litigation and advocacy relying on domestic constitutional and legislative equality or non-discrimination provisions, sometimes with the use of international or transnational jurisprudence to assist progressive interpretations ... may carry a greater domestic legitimacy and authority than international jurisprudence. ${ }^{167}$

For a state such as the UK, with, at present, strong national human rights protection, procedurally and substantively the same as that offered by the ECHR and ECtHR, an independent and impartial judiciary, and a relatively robust civil society, it may be that more can be achieved at the national level, in effect, saving the ECtHR from getting involved in difficult and sensitive issues, and preserving the Convention system for those States experiencing more pressing and gross violations of Convention rights.

162 K. Alter, The New Terrain of International Law (Princeton: Princeton University Press, 2014), p. 24.

163 H. Fenwick, "Same sex unions at the Strasbourg Court in a divided Europe: driving forward reform or protecting the Court's authority via consensus analysis" (2016) European Human Rights Law Review $248,249$.

164 C. DraghicI, "The Strasbourg Court between European and local consensus: anti-democratic or guardian of democratic process?” (2017) Public Law, 11, 28.

165 K. Henrard, "How the European Court of Human Rights" concern regarding European consensus tempers the effective protection of freedom of religion' (2015) 4 Oxford Journal of Law and Religion, 398, 414.

166 T. LEWIS and P. CuMPER, "Balancing freedom of political expression against equality of opportunity: the courts and the UK's broadcasting ban on political advertising" (2009) Public Law 89.

167 D. MCGOLDRICK, "The development and status of sexual orientation discrimination under international human rights law" (2016) 16 Human Rights Law Review, 613, 664. 
Título: De la dinámica a la estática: evolución de la relación entre el Reino Unido y el Tribunal Europeo de Derechos Humanos.

ABSTRACT: In this article the evolution of the relationship between the UK and the European Court of Human Rights is examined. With strong buman rights protection through law now present at the national level, it is concluded that the relationship has moved from a dynamic to static. The implications of this for the protection of human rights in the $U K$ are considered and evaluated.

RESUMEN: En este artículo se examina la evolución de la relación entre el Reino Unido y el Tribunal Europeo de Derechos Humanos. Teniendo en cuenta que ya existe a nivel nacional una importante garantía y protección de los derechos fundamentales, se observa que la relación ha cambiado de dinámica a estática. Las implicaciones que este paradigma tiene para el caso particular del Reino Unido será objeto de examen y discusión.

KEY WORDS: European Court of Human Rights, UK.

PalabRas ClaVE: Tribunal Europeo de Derechos Humanos, Reino Unido.

FECHA DE RECEPCIÓN: 29.06.2018 FECHA DE ACEPTACIÓN: 13.09.2018 